\title{
The Premature Burial of Telecommunications Reform: A Response to John Quiggin
}

\author{
Rodney Maddock
}

\begin{abstract}
$\int$
OHN QUIGGIN has recently argued in this journal that 'the main deficiency in Australian telecommunications policy has been the failure to take adequate account of natural monopoly' (Quiggin, 1998:428). It is true that there have been significant weaknesses in the performance of the telecommunications industry, and that many of these weaknesses can be attributed to regulatory choices. But it is by no means clear that they have emerged as a result of any natural monopoly in telecommunications. Furthermore, it is instructive to compare Quiggin's analysis with that of AT\&T, which at the turn of the 20th century convinced regulators that having 4,000 interconnected telecommunications companies resulted in wasteful duplication, thus promoting a regulatory regime which created the AT\&T monopoly (Mesher \& Zajac, 1998).

As has often been observed, many countries are opening up their telecommunications sectors by removing legal restrictions and other entry barriers. Once markets are opened in this way, a multitude of telecommunications carriers have chosen to enter. Such rapid and widespread entry into a sector is hardly an indicator of pervasive natural monopoly of the sort Quiggin is concerned about.

Quiggin's argument is complex. He proceeds from the contention that any local network in telecommunications constitutes a natural monopoly. He infers from this that the policy decision to support facilities-based competition in Australia, and especially network duplication, was fundamentally misconceived. Thus, a range of policy decisions related to competition in fixed networks, mobile phones, and so forth, were wrong. In his view, mistakes about the technology led to policies that have encouraged wasteful duplication of investment and have dissipated many of the benefits that Australians might otherwise have enjoyed. Finally, he argues that the appropriate policy is to nationalise Telstra, to reserve to that enterprise a legislated monopoly over local telecommunications infrastructure, and to impose on it common-carrier obligations.
\end{abstract}

\footnotetext{
${ }^{1}$ A large number of countries have allowed competition at the local level. Entry has been slow but not insignificant.
}

Rodney Maddock is Professor of Economics at La Trobe University. 


\section{What Natural Monopoly?}

The issue of whether there is a natural monopoly in telecommunications is crucially important to policy choices. If some part of the network involved a naturalmonopoly technology, it might be sensible to bar entry to it by imposing an appropriate regulatory regime to prevent abuse of the monopoly. Whether such a natural monopoly exists will depend on a number of factors such as the degree of substitution between it and other goods, the possibility of competition from other technologies, and the size of the rents extracted by the monopolist (King \& Maddock, 1996).

Quiggin assumes that there is a natural monopoly in local telecommunications: 'it will be assumed that economies of scale ... apply to local services of all kinds, but not to long-distance services' (p. 429). He then argues that only one company, Telstra, should be able to provide this service. The problem, however, is far more complicated than this.

Empirical evidence. So far, and as reported by Quiggin, econometric studies have yielded little evidence of natural monopoly in telecommunications.

The Industry Commission has recently surveyed the Australian and international evidence on the issue of whether telecommunications is characterised by natural monopoly. It concludes that 'no conclusive empirical evidence exists which proves or disproves that the local network has cost characteristics conducive to natural monopoly' (1997:29).

In a project I was involved in for the Asian Development Bank (1994), we evaluated carefully a number of different technologies for the delivery of local telephone services in India. Based on the quotes given to the project team from a variety of equipment suppliers, we calculated that installing a fixed cellular telephone system would cost about US $\$ 1,000$ per connection. This was about 40 per cent below the local telephone monopoly's estimate for providing the same number of wired services. The International Telecommunications Union (ITU) (1994) estimated that each additional line in India cost over US $\$ 2,000$, or double our estimate of the cost of using an alternative technology.

If we had followed Quiggin's rule, we would have recommended that the new technology not be allowed to enter and, as a result, the cost of expanding the Indian system would have been 40 per cent higher. The cost to Indian consumers would thus have been at least US $\$ 60 \mathrm{~m}$ more than the actual project costs. If the ITU estimates are to be believed rather than those of the local monopolist, then expanding the local network through the local monopoly would have cost Indian consumers US $\$ 150 \mathrm{~m}$ more than was necessary.

The inference is that, even if Quiggin is right and local services are natural monopolies, allowing an entrenched monopolist to operate them does not necessarily lead to desirable social outcomes. Firms that are protected from entry by legislation can operate very inefficiently. The alternative inference is that local services are not necessarily natural monopolies after all. 
Which market? The second problem with the claim that local networks are natural monopolies lies in the difficulty in determining a priori the relevant market. Telstra in recent years has reconfigured its telephone network. The main effect of this has been to eliminate a tier of switches that were relatively close to consumers, thus reducing the total number of intelligent switching points in the network. If local networks are natural monopolies, then the area of the natural monopoly has been expanded by the network reconfiguration. In the extreme, Australia could be converted into a single local network with one massive intelligent switch driving the system. While this would not reflect optimal network design, it would be a logical direction for Telstra to take if local networks were to be legislated natural monopolies. The essential point is that the definition of what is 'local' in local networks is ambiguous and endogenous rather than simply given by technology.

To complicate matters further, the definition of a local network also depends on the technology chosen. In a satellite system, the local network in Quiggin's conception would probably consist of the satellite footprint, which may well include all of eastern Australia. Alternatively, in an interactive cable television system where intelligent switching needs to be decentralised, local networks may be much smaller. Do we want policy-makers to decide that neither satellite nor cable should be allowed because they overlap in some dimensions with a legislated natural monopoly? Alternatively, do we allow the existing monopolist over local telephone systems to have exclusive rights to all other technologies that might emerge and compete with them?

A third complication can arise since there may be many local networks within the one telephone system, each of which could conceivably be operated by a separate local monopolist. The presence of economies of scale at the local level is not an argument for giving a monopoly over local services in all locations to any one firm.

Which technology? The discussion above has already introduced the theme of technological choice. Telephone messages can be sent by a wide range of technologies, with 'new' possibilities emerging regularly. In addition to the copper wires and fibre optics used in traditional systems, wireless systems such as cellular telephony or satellite, and alternative wired systems including cable television by e-mail and even over power lines, provide an increasing range of technological choices.

When Quiggin argues that local telephony is a natural monopoly, he is clearly making some judgment as to the appropriate technology. A given technology considered alone may have the characteristics of a natural monopoly, and one imagines Quiggin would say that was true of copper wired systems. But it seems highly unlikely that this would be true over all ranges of output, as required by natural monopoly tests. The Indian example cited above seems to provide clear evidence that different technologies may be appropriate in different circumstances and that technologies may well overlap. 


\section{Regulatory Failures}

Policy-makers who are uncertain about whether any particular technology has natural monopoly characteristics and about how technology will develop, but are aware that technology is changing rapidly, would be foolish to regulate to the effect that local networks provided by copper wire technology were a natural monopoly. In my judgment, the policy-makers made the only realistic choice available to them. They first corporatised Telstra from 1988 and encouraged it to operate commercially. They then opened the market to other participants and allowed firms to make technological decisions. They have also created rights of access whereby third parties can utilise the facilities of others subject to a declaration test. ${ }^{2}$ But why then has the performance of the telecommunications industry not been better?

Quiggin claims to have identified three major failures of policy: Telstra remains dominant in most markets but is far less susceptible to policy controls than when it was a government department; prices have fallen only to the extent dictated by regulation and this has simply followed past trends; and much investment has gone into network duplication.

The first of these 'failures' hardly seems like one. Governments of various persuasions in Australia and elsewhere have moved away from operating government businesses from government departments towards corporate models. They have done so because of perceived and actual failures of the bureaucratic model of management. Quiggin appears to believe that this policy has been a failure in telecommunications; but I find it difficult to imagine that Australia Post and the national Telecom (before it merged with the Overseas Telecommunications Corporation, OTC, from 1991), operating as government departments, would have demonstrated the same verve as they have shown since being corporatised. The transformation of Australia Post in particular has been striking. Improved operation of enterprises has imposed a cost in the form of the necessity of developing alternative mechanisms of control. At least in the case of Australia Post, these alternative structures have in my opinion been effective (Castro \& Maddock, 1997).

As for Quiggin's concern that telecommunications prices have fallen only at the pace prescribed by regulation, the very fact that Telstra's prices have followed the dictates of the price cap demonstrates directly that this policy tool, at least, has been effective in managing Telstra. But there are two important issues here: whether the cap should have forced a faster pace of price reductions and whether competition would have resulted in faster reductions than those required by the cap. It is quite clear to me that the cap was set too conservatively: the $\mathrm{X}$ in the 'CPI minus X' formula has been raised successively, and Telstra continues to make very large profits. While the cap has forced the telecommunications carriers to pass on significant benefits to consumers, limiting the policy of restricting entry to various markets to a specific period (so confining entry to Optus, or Optus and Vodafone) gave the car-

\footnotetext{
The declaration test is not exactly a natural monopoly test but has some of the same flavour. In practice it will allow access in a wider range of circumstances and with fewer proofs than would be necessary under a natural monopoly test.
} 
riers every incentive to price up to the cap. This strategy generated revenues that they were able to use to finance infrastructure that would make it difficult for subsequent entrants to compete. The important policy decision was that of restricting entry.

Quiggin's third major policy concern is that there has been considerable duplication of investment. Duplicate investment occurs in most markets: Coles-Myers and Woolworths, Shell and BP, and so forth. Duplication of investment is normal commercial practice. So why is it a concern in telecommunications? The central issue seems to be that the local networks may be natural monopolies and should therefore not normally be duplicated. Clearly such a view requires further modification. Presumably, Quiggin would not want to restrict competition between technologies, and would allow local telephony to be provided by cable and copper wires, and by cellular systems and by satellite, even though this would already involve considerable duplication of function. His concern thus comes down to cases of two or more enterprises building duplicate networks based on the same technology. Should the government stop firms from doing this? It is clear that local petrol stations have important economies of scale in terms of 'potential cost savings from ... serving more customers in any one [market]' (p. 428). Do we really want the government to stop petrol companies building stations close to one another?

In telecommunications, if companies were private and making their own decisions, then there would be no case for government restricting their investment choices. If a firm chooses to enter a market where an incumbent firm has lower costs due to economies of scale, then it loses its money. Where one of the firms is a public enterprise, then taxpayers should be concerned because it is their money that is put at risk. Even worse would be the situation where regulators allowed a firm which made a poor investment to earn higher returns in some other segment to compensate it for its mistaken decisions. Our concern with the telecommunications choices that have been made arises largely because one of the firms involved in duplicating investment is a (partially) public enterprise. It is not clear that taxpayers should be required to underwrite technological risks taken by telephone companies: this is one of the central rationales of privatisation.

\section{Alternative Rationalisation of the Failures}

The central policy failures in telecommunications thus seems to have arisen from two decisions: the attempt to manage the industry by the policy of the staged entry of Optus and Vodafone in the hope that they would emerge as facility-based competitors for the integrated Telstra, and the investment risks Telstra has chosen to incur while in public hands.

\footnotetext{
${ }^{3}$ Recall that OTC was considered as a possible base for an alternative carrier to Telecom when the reform strategy was developed. The 1991 decision to integrate the two into Telstra represented a victory for Kim Beazley, the Minister of Telecommunications, over Paul Keating, the Treasurer.
} 
In order to understand these policy choices, it is necessary to revisit the policy environment of the early 1990s. The telecommunications sector consisted of three public monopolies. Telecom had a national monopoly of land-based national telephone services; OTC had a monopoly of international calling; and AUSSAT had a monopoly of satellite telephony. The policy that emerged was a compromise. In order to be able to introduce any competition at all into local markets, the government was forced to strengthen Telecom by adding OTC to it. Without this compromise, the Labor Party would not have allowed the Hawke Government to proceed with reform. By turning the incumbent firm into an integrated monopolist, the government significantly weakened the possibility of effective competition.

The second major concern was that AUSSAT was in debt to the tune of about $\$ 800 \mathrm{~m}$. Quayle (1987) has attributed this to AUSSAT's failure to emerge as an integrated part of the Telecom network because of Telecom's opposition to potential competition. In order to mask this, the government required the new entrant to absorb AUSSAT as part of its effective licence fee for becoming a telecommunications carrier. Such a licence fee would be valuable only if Optus were able to extract some rents from its decision to enter. Thus, further entry was restricted, prices were higher than they would otherwise have been, and many of the anomalies in the current structure became unavoidable." The policy-makers knew that this was likely to occur. Their quid pro quo was the deadline of 1997 for opening the markets; they foresaw that the benefits from competing facilities would emerge after this date, not before.

The alternative explanation of the weaknesses of the reform process to date is best explained theoretically by Brennan and Buchanan (1985), who argue that what they call 'constitutional change' is difficult to effect in a democracy. In order to make major changes, governments are obliged to accede to the demands of interest groups in the short run, which effectively postpones the changes to a point of time in the future. But the agents involved in the policy decision are unlikely to be able to foresee exactly where their particular interests will lie at that future date, and hence are likely to frame their future choices in the light of the public interest rather than their private interest. Maddock (1994) explains telecommunications reform in Australia from this perspective.

\section{The Way Forward}

Quiggin argues that the appropriate policy for the future in Australian telecommunications involves three steps: the nationalisation of Telstra, the prohibition of entities other than Telstra providing local wire-based telephony or cable TV facilities, and Telstra's divestiture of content-provision interests and digital cellular services. Telstra would be allowed to provide long-distance telephony, international telephony and analog mobile services. Regulation would be required to prevent Telstra

\footnotetext{
4 It is interesting to note, however, that satellite is emerging as an important element of service provision in competition with other technologies in the late 1990s. The extent to which Optus has been handicapped by the incorporation of AUSSAT is not clear.
} 
overcharging households for facilities and overcharging content providers for carrying content.

The alternative approach is far less restrictive: it is to allow the current structure to work itself out. The period 1992-97 was always accepted as a compromise; only since then has reform truly started. To the extent that the government policy has been predicated on competing facilities and technologies, it is obviously far too early to evaluate the outcome. What some might see as a failure of firms to pass on benefits to consumers, others see as the retention of earnings to finance investment. Australia has chosen a long-run strategy that can fairly be judged only in the long run (see Bowles \& Maddock, 1998, for a comparison with Chilean policy). The full privatisation of Telstra is the last remaining fundamental reform. Once that happens, private firms will be able to make their own technological choices and put their own shareholders' funds at risk.

Under the reform strategy, the regulation of access and of some prices is intended to protect consumers and competitors from abuses of monopoly power. The same (even potentially weaker) regulations would be required under the nationalisation model.

The strength of Quiggin's policy proposal is that it uses government regulations to prevent (private and government) firms from constructing certain facilities and hence possibly wasting their own funds. Its weaknesses are that it requires policymakers to make judgments about appropriate technologies, to define local network boundaries, and to prohibit other firms from making desired investments. These are not the sorts of decisions governments have been good at making in the past. The failure of the AUSSAT experiment, under which certain firms were given monopolies over different technologies, is one such example.

Quiggin contends that 'despite radical changes in telecommunications policy, changes in the telecommunications market, particularly for services to residential users, have been modest' (p. 432). Perhaps this view depends on how the word 'market' is interpreted. But households have seen major reductions in call charges, especially large reductions in international calls, a significant expansion in the range of services available with e-mail and Internet access, 1800 numbers, call-back services and the like, as well as the facility to perform a wide range of basic activities over the telephone. Households now have a much wider range of services, and a far greater choice of providers for many services, than in 1991, when the reforms began. Certainly in my own household, the role of the telephone has been transformed.

\section{References}

Asian Development Bank (1994), 'Draft Report on a Proposed Loan to the Government of India for the Development of Rural Telecommunications', prepared by Ambidji Group, Manila.

Bowles, D. \& R. Maddock (1998), 'Competition in Long Distance Telephones: Unleashed In Chile, Unwrapped in Australia', pp. 25-38 in S. McDonald and G. Madden (eds), Telecommunications and Socio-conomic Development, Elsevier Science, North Holland. 


\section{Rodney Maddock}

Buchanan, J. \& G. Brennan (1985), The Reason of Rules: Constitutional Political Economy, Cambridge University Press, Cambridge.

Castro, M. \& R. Maddock (1997), 'The Universal Service Obligation for Australia Post: Some Australian Calculations', pp. 258-69 in M. Crew \& P. Kleindorfer, Managing Change in the Postal and Delivery Industries, Kluwer Academic Press, Boston.

Industry Commission (1997), Telecommunications Economics and Policy Issues, Staff Information Paper, Australian Government Publishing Service, Canberra.

International Telecommunications Union (1994), World Telecommunication Development Report, Geneva.

King, S. \& R. Maddock (1996), 'Competition and Almost Essential Facilities: Making the Right Policy Choices', Economic Papers 15(3): 28-37.

Maddock, R. (1994), 'Microeconomic Reform as Constitutional Political Economy: A Commentary on Hilmer', Economic Papers.13(2): 27-38.

Mesher, G. \& E. Zajac (1998), 'Toward a Theory of the Global Liberalisation of Telecommunications', paper presented to the International Telecommunications Conference, Stockholm.

Quayle, M. (1987), 'An Assessment of Australia's Domestic Satellite Communications Policy: A Case Study', Public Policy Unit, Department of Public Policy and Management, Australian National University, Canberra (Case Study No. 8).

Quiggin, J. (1998), "The Premature Burial of Natural Monopoly: Telecommunications Reform in Australia', Agenda 5: 427-40. 